\title{
PENGARUH PEMANFAATAN MEDIA PEMBELAJARAN DAN KEMAMPUAN BERPIKIR KREATIF TERHADAP HASIL BELAJAR PEMAHAMAN MEMBACA BAHASA INGGRIS
}

\author{
Sahara $^{1}$, Harun Sitompul ${ }^{2}$, Keysar Panjaitan ${ }^{3}$ \\ ${ }^{1}$ Sekolah Menengah Pertama Swasta Methodist 6 Medan, Sumatera Utara \\ ${ }^{2,3}$ Pascasarjana Universitas Negeri Medan \\ sarahcancer68@gmail.com ${ }^{1}$
}

\begin{abstract}
Abstrak: Penelitian ini bertujuan untuk mengetahui: (1) hasil belajar Pemahaman Membaca Bahasa Inggris siswa yang diajar dengan pemanfaatan media pembelajaran berbasis komputer lebih tinggi dengan media berbasis audio visual, (2) hasil belajar Pemahaman Membaca Bahasa Inggris siswa yang memiliki kemampuan berpikir kreatif tinggi lebih tinggi dengan berpikir kreatif rendah dan (3) interaksi antara media pembelajaran dengan kemampuan berpikir kreatif dalam mempengaruhi hasil belajar Pemahaman Membaca Bahasa Inggris siswa. Metode penelitian yang digunakan adalah quasi eksperimen dengan desain faktorial $2 \times 2$. Teknik analisis yang digunakan adalah analisis varians dua jalur (Two Way Anava $2 x 2$ ) dengan taraf signifikansi $\alpha=0,05$ dengan menggunakan Uji-F, pengujian uji lanjut menggunakan uji Tuckey. Temuan penelitian menunjukkan: (1) terdapat perbedaan yang signifikan antara hasil belajar Pemahaman Membaca Bahasa Inggris siswa yang diajar dengan pemanfataan media pembelajaran berbasis komputer dengan media berbasis audio visual, (2) terdapat perbedaan yang signifikan antara hasil belajar Pemahaman Membaca Bahasa Inggris siswa yang memiliki kemampuan berpikir kreatif tinggi dengan berpikir kreatif rendah, dan (3) tidak ada interaksi antara media pembelajaran dan kemampuan berpikir kreatif sehingga media pembelajaran dapat dimanfaatkan untuk siswa yang memiliki kemampuan berpikir kreatif tinggi maupun rendah dalam penguasaan materi pembelajaran sehingga hasil belajar Pemahaman Membaca Bahasa Inggris yang diperoleh siswa tinggi.
\end{abstract}

Kata Kunci: media pembelajaran, kemampuan berpikir kreatif terhadap hasil belajar pemahaman membaca bahasa Inggris

\begin{abstract}
This study aims to determine: (1) the results of studying reading Comprehension for students who are taught by media computer based learning is higher than audio visual media, (2) the results of learning Reading Comprehension for students who have the high creative thinking ability is higher than low ones and (3) interaction between learning media and creative thinking skills in influencing students' learning outcomes of Reading Comprehension. The method used is a quasi-experimental design with 2 x 2 factorial. The analysis technique using the analysis of variance of two lanes (Two Way Anova $2 \times 2$ ) with significance level $\alpha=0.05$ using the Test-F, a further test testing use Tuckey test. The findings show: (1) there is a significant difference between the results of studying Reading Comprehension for the students who are taught by media computer based learing and audio visual media, (2) there is a significant difference between the results of studying Reading Comprehension for students who have the creative thinking ability higher than the low ones, and (3) there is no interaction between the learning media and creative thinking ability, then media computer based learning can be used for the students that have high creative thinking ability or the low ones to give the effect in mastering the learning material then the learners' could get the high achievement in Reading Comprehension.
\end{abstract}

Keywords: learning media, the creative thinking ability towards the learning outcomes of Reading Comprehension

\section{PENDAHULUAN}

Pembangunan pendidikan merupakan suatu hal yang sangat penting untuk diperhatikan. Melalui pembangunan sumber daya manusia (SDM) di bidang pendidikan merupakan modal utama dalam pembangunan bangsa. Untuk menghadapi persaingan dalam era globalisasi, pemerintah berusaha mengantisipasi melalui peningkatan kualitas sumber daya manusia dengan cara peningkatan kualitas pendidikan. Hal ini sesuai dengan Undang-Undang Nomor 20 Tahun 2003 tentang Sistem Pendidikan Nasional menyatakan bahwa: Pendidikan Nasional berfungsi mengembangkan kemampuan dan membentuk watak serta peradaban bangsa yang bermartabat dalam rangka mencerdaskan kehidupan bangsa, bertujuan untuk mengembangkan potensi 
peserta didik agar menjadi manusia yang beriman dan bertaqwa kepada Tuhan Yang Maha Esa, berakhlak mulia, sehat, berilmu, cakap, kreatif, mandiri dan menjadi warga negara yang demokratis dan bertanggung jawab.

Miarso (2007: 486) mengatakan bahwa "sumber daya manusia merupakan modal dasar pembangunan terpenting". Lebih lanjut dijelaskan pendidikan untuk pembangunan kualitas manusia meliputi segala aspek perkembangan manusia dalam harkatnya sebagai makhluk yang berakal budi, sebagai pribadi, sebagai masyarakat dan sebagai warga negara.

Permasalahan ini dapat diminimalkan apabila guru sewaktu mengajar menggunakan strategi pengorganisasian media pembelajaran yang tepat dan dapat membantu siswa dalam meningkatkan mutu dan keterampilannya. Hambatan lain yang terbesar dalam mengimplementasikan kurikulum 2013 bagi sebagian besar guru adalah karena kurangnya pengetahuan guru tentang Design Pembelajaran, yaitu suatu disiplin ilmu yang berkaitan erat dengan rancang bangun mata pelajaran atau kurikulum mata pelajaran atau kurikulum mikro serta penguasaan IPTEK yang kurang terutama dalam merancang media pembelajaran berbasis komputer yang mampu membantu siswa memahami materi dari mata pelajaran yang diajarkan kepada siswa.

Media pembelajaran berbasis komputer ini mampu mengubah hal-hal yang abstrak menjadi konkrit, praktis digunakan sebagai salah satu sumber belajar secara luas (using broad range learning resources) maupun belajar secara individual dan personal (individualized and personalized learning) serta pendekatan sistem dalam memecahkan masalah-masalah belajar (using system approach) karena adanya software aplikasi pendukung materi mata pelajaran tersebut.

Media pembelajaran itu sangat banyak ragamnya, dari media yang berbentuk audio, media visual, media audio visual, radio, televisi, komputer, proyektor, perpustakaan, laboratorium, pusat sumber belajar dan berbagai sumber belajar serta fasilitas lainnya. Dewasa ini bidang pembelajaran secara umum sedikit banyaknya terpengaruh oleh adanya perkembangan dan penemuan-penemuan dalam bidang ketrampilan, ilmu, dan teknologi. Pengaruh perkembangan tersebut tampak jelas dalam upaya-upaya pembaruan sistem pendidikan. Perkembangan ilmu pengetahuan dan teknologi semakin mendorong upaya-upaya pembaharuan dalam pemanfaatan hasil-hasil teknologi dalam proses belajar. Para guru dituntut agar mampu menggunakan alat-alat yang dapat disediakan oleh sekolah, dan tidak tertutup kemungkinan bahwa alat-alat tersebut sesuai dengan perkembangan dan tuntutan zaman. Guru sekurang-kurangnya dapat menggunakan alat yang murah dan efisien, meskipun sederhana dan bersahaja, tetapi merupakan keharusan dalam upaya mencapai tujuan pengajaran yang diharapkan.

Secara umum, dalam strategi pembelajaran ada 3 (tiga) tahapan pokok yang harus diperhatikan dan diterapkan (Riyanto, 2012:132-133) sebagai berikut: (1) tahap pemula (pra-instruksional), adalah tahapan persiapan guru sebelum kegiatan pembelajaran dimulai, (2) tahap pengajaran (instruksional), yaitu langkah-langkah yang dilakukan saat pembelajaran berlangsung, dan (3) tahap penilaian dan tindak lanjut (evaluasi), ialah penilaian atas hasil belajar siswa setelah mengikuti pembelajaran dan tindak lanjutnya. Tahapan-tahapan tersebut memiliki hubungan erat dengan pemanfaatan media pembelajaran. Oleh karena itu, setiap pemanfaatan media pembelajaran harus merupakan rangkaian yang utuh dengan tahapan-tahapan pengajaran.

Media berasal dari bahasa Latin yang mempunyai arti antara. Makna tersebut dapat diartikan sebagai alat komunikasi yang digunakan untuk membawa suatu informasi dari suatu sumber kepada penerima. Media adalah segala bentuk dan saluran yang digunakan untuk menyalurkan pesan atau informasi. Apabila dikaitkan dengan kegiatan pembelajaran maka media dapat diartikan sebagai alat komunikasi yang digunakan dalam proses pembelajaran untuk membawa informasi dari pengajar ke peserta didik dalam Heinich, et.al seperti dikutip Uno dan Lamatenggo (2011:121).

Menurut Gerlach dan Ely seperti yang dikutip Arsyad (2013:3) mengatakan bahwa media apabila dipahami secara garis besar adalah manusia, materi, atau kejadian yang membangun kondisi yang membuat siswa mampu memperoleh pengetahuan, ketrampilan, atau sikap. Dalam pengertian ini, guru, buku teks, dan lingkungan sekolah merupakan media. Secara lebih khusus, pengertian media dalam proses belajar mengajar cenderung diartikan sebagai alat-alat 
grafis, photografis, atau elektronis untuk menangkap, memproses, dan menyusun kembali informasi visual atau verbal.

Heinich, et.al, yang dikutip Arsyad (2013:3-4) mengemukakan istilah medium sebagai perantara yang mengantar informasi antara sumber dan penerima. Apabila media itu membawa pesan-pesan atau informasi yang bertujuan instruksional atau mengandung maksud-maksud pengajaran maka media itu disebut media pembelajaran. Sejalan dengan batasan ini, Hamidjojo dalam Latuheru, seperti dikutip Arsyad (2013:4) memberi batasan media sebagai semua bentuk perantara yang digunakan oleh manusia untuk menyampaikan atau menyebar ide, gagasan, atau pendapat sehingga ide, gagasan atau pendapat yang dikemukakan itu sampai kepada penerima yang dituju.Dengan kata lain, media adalah komponen sumber belajar atau wahana fisik yang mengandung materi instruksional di lingkungan siswa yang dapat merangsang siswa untuk belajar.

Berdasarkan batasan yang telah disampaikan oleh para ahli mengenai media, maka dapat disimpulkan bahwa pengertian media adalah segala bentuk alat komunikasi yang dapat digunakan untuk menyampaikan informasi dari sumber ke peserta didik dalam kegiatan pembelajaran. Tujuannya adalah merangsang mereka untuk mengikuti kegiatan pembelajaran dengan baik sehingga memperoleh hasil belajar yang baik. Selain digunakan untuk mengantarkan pembelajaran secara utuh, dapat juga dimanfaatkan untuk menyampaikan bagian tertentu dari kegiatan pembelajaran, memberikan penguatan maupun motivasi supaya para siswa lebih mudah memahami materi pembelajaran yang dipelajari dari guru.

Dengan menggunakan media pembelajaran yang dipersiapkan dengan baik berarti guru atau pendidik telah membantu siswanya mengaktifkan unsur-unsur psikologis yang ada dalam diri siswa seperti: pengamatan, daya ingat, minat, perhatian, berpikir, fantasi, emosi dan perkembangan kepribadian mereka. Sikap jiwa siswa yang tenang dengan minat belajar yang besar sangat potensial sekali ditumbuhkembangkan sebagai dasar materi keimanan, ibadah, sikap sosial, pembentukan akhlak dan sebagainya (Arsyad, 1996: 59).

Dengan demikian dapat dikatakan bahwa penggunaan media pembelajaran bukan sekedar upaya untuk membantu guru dalam mengajar, tetapi lebih dari itu sebagai usaha yang ditujukan untuk memudahkan siswa dalam pembelajaran. Akhirnya media pembelajaran memang pantas digunakan oleh guru, bukan hanya sekedar alat bantu mengajar bagi guru, namun diharapkan akan timbul kesadaran baru bahwa media pembelajaran telah menjadi bagian integral dalam sistem pendidikan sehingga dapat dimanfaatkan semaksimal mungkin untuk membantu lancarnya bidang tugas yang diemban untuk kemajuan dan meningkatkan kualitas peserta didik.

Sementara itu, Gagne dan Briggs seperti dikutip Setijadi (1986:26) secara implisit mengatakan bahwa media pembelajaran meliputi alat yang secara fisik digunakan untuk menyampaikan isi materi pengajaran, yang terdiri dari antara lain buku, tape recorder, kaset, video kamera, video recorder, film, slide (gambar bingkai), foto, gambar, grafik, televisi, dan komputer. Jenis media yang dimanfaatkan dalam proses pembelajaran cukup banyak ragamnya, mulai dari media yang sederhana, sampai pada media yang cukup rumit dan canggih. Untuk mempermudah mempelajari jenis media, karakter, dan kemampuannya dilakukan pengklasifikasian atau penggolongan.

Penggolongan yang dikemukan Arsyad (2013:122-123) dapat dijadikan acuan dalam pemanfaatan media adalah berdasarkan pada teknologi yang digunakan, mulai media yang teknologinya rendah (low technology) sampai pada media yang menggunakan teknologi tinggi (high technology). Apabila penggolongan media ditinjau dari teknologi yang digunakan, maka penggolongannya sangat dipengaruhi oleh perkembangan teknologi. Dengan demikian penggolongan media dapat berubah dari waktu ke waktu. Misalnya dalam era tahun 1950 media televisi dikategorikan sebagai media berteknologi tinggi, tetapi kemudian pada era tahun 19701980 media tersebut bergeser dengan kehadiran media komputer.Pada masa tersebut komputer digolongkan sebagai media dengan teknologi yang paling tinggi oleh Heinich,et.al, yang dikutip Uno dan Lamatenggo (2011:123). Tetapi kemudian pada tahun 1990 tergeser kedudukannya dengan kehadiran media komputer conferencing melalui internet.

Berdasarkan definisi sumber belajar sebagaimana diberikan di atas, maka media pembelajaran dan sumber belajar memiliki 
kesamaan di suatu sisi dan juga perbedaan di sisi lain. Persamaannya, ketika media berfungsi sebagai sumber untuk membantu individu dalam proses pembelajaran. Misalnya, media video yang berisi materi atau bahan pembelajaran digunakan untuk membantu proses pembelajaran baik dalam ruang kelas ataupun di luar ruang kelas, maka kedudukan media video tersebut sama dengan sumber belajar. Tetapi jika media visual yang hanya berfungsi sebagai peralatan fisik saja, berfungsi sebagai perantara antara sumber dengan penerima informasi, maka peralatan visual tersebut hanyalah media dan bukan sebagai sumber belajar. Dari perspektif ini, media pembelajaran lebih sempit dari sumber belajar.

Gerlach dan Ely yang diutip Arsyad (2013: 15) mengemukakan tiga ciri media yang merupakan petunjuk mengapa media digunakan dan apa-apa saja yang dapat dilakukan oleh media yang mungkin guru tidak mampu (atau kurang efisien) melakukannya. Ketiga ciri-ciri media tersebut adalah : (1) ciri fiksatif (fixative property), ciri ini menggambarkan kemampuan media merekam, menyimpan, melestarikan, dan merekonstruksi suatu peristiwa atau objek. Suatu peristiwa atau objek dapat diurut dapat diurut dan disusun kembali dengan media seperti fotografi, video tape, audio tape, flashdisk, dan film; dengan ciri fiksatif ini, media memungkinkan suatu rekaman kejadian atau objek yang terjadi pada satu waktu tertentu ditransportasikan tanpa mengenal waktu; (2) ciri manipulatif (manipulative property) memungkinkan transformasi suatu kejadian atau objek. Kejadian yang memakan waktu berhari-hari dapat disajikan kepada siswa dalam waktu dua atau tiga menit dengan teknik pengambilan gambar time-lapse recording; manipulasi kejadian atau objek dengan jalan mengedit hasil rekaman dapat menghemat waktu; (3) ciri distributif (distributive property) dari media memungkinkan suatu objek atau kejadian ditransportasikan melalui ruang, dan secara bersamaan kejadian tersebut disajikan kepada sejumlah besar siswa dengan stimulus pengalaman yang relatif sama mengenai kejadian itu;dewasa ini, distribusi media tidak hanya terbatas pada satu kelas atau beberapa kelas pada sekolah-sekolah di dalam suatu wilayah tertentu, tetapi juga media itu misalnya rekaman video, audio, flashdisk dapat disebar ke seluruh penjuru tempat yang diinginkan kapan saja; sekali informasi direkam dalam format media apa saja, ia dapat direproduksi seberapa kali pun dan siap digunakan secara bersamaan di berbagai tempat atau digunakan secara berulang-ulang di suatu tempat; konsistensi informasi yang telah direkam akan terjamin sama atau hampir sama dengan aslinya.

Dalam suatu proses pembelajaran, dua unsur yang amat penting adalah metode mengajar dan media pembelajaran. Kedua aspek ini saling berkaitan. Pemilihan salah satu metode mengajar tertentu akan memengaruhi jenis media pembelajaran yang sesuai, meskipun masih ada berbagai aspek lain yang harus diperhatikan dalam memilih media, antara lain tujuan pembelajaran, jenis tugas dan respon yang diharapkan siswa kuasai setelah pembelajaran berlangsung, dan konteks pembelajaran termasuk karakteristik siswa. Meskipun demikian, dapat dikatakan bahwa salah satu fungsi utama media pembelajaran adalah sebagai alat bantu mengajar yang turut mempengaruhi iklim, kondisi, dan lingkungan belajar yang ditata dan diciptakan oleh guru.

Media pembelajaran, memurut Kemp dan Dayton (1985:28), dapat memenuhi tiga fungsi utama apabila media itu digunakan untuk perorangan, kelompok atau kelompok pendengar yang besar jumlahnya, yaitu: (1) memotivasi minat atau tindakan, (2) menyajikan informasi, dan (3) memberi instruksi. Untuk memenuhi fungsi motivasi, media pembelajaran dapat direalisasikan dengan teknik drama atau hiburan. Hasil yang diharapkan adalah melahirkan minat dan merangsang para siswa atau pendengar untuk bertindak (turut memikul tanggung jawab.melayani secara sukarela, atau memberikan sumbangan material). Pencapaian tujuan ini akan mempengaruhi sikap, nilai dan emosi.

Media pembelajaran berbasis informasi teknologi maksudnya adalah media yang menggunakan teknologi, misalnya pemakaian komputer dalam kegiatan pembelajaran untuk tujuan kognitif, psikomotor dan afektif. Tujuan kognitif komputer dapat mengajarkan konsepkonsep aturan, prinsip, langkah-langkah, proses, dan kalkulasi yang komples. Komputer juga dapat menjelaskan konsep tersebut secara sederhana dengan penggabungan visual dan audio yang dianimasikan, sehingga cocok untuk kegiatan pembelajaran mandiri.Tujuan Psikomotor bentuk pembelajaran komputer dapat dikemas dalam bentuk games dan simulasi yang sangat bagus digunakan untuk menciptakan kondisi dunia kerja. Beberapa 
contoh program antara lain; simulasi pendaratan pesawat, simulasi perang dalam medan yang paling berat dan sebagainya. Dan tujuan afektif komputer bilamana program didesain secara tepat dengan memberikan potongan clip suara atau video yang isinya menggugah perasaan, pembelajaran sikap/afektif pun dapat dilakukan menggunakan media komputer.

Media audio-visual ini dapat dibagi menjadi dua jenis. Jenis pertama, dilengkapi fungsi peralatan suara dan gambar dalam satu unit, dinamakan media audio-visual murni, seperti film gerak (movie) bersuara, televisi dan radio. Jenis kedua adalah media audio-visual tidak murni yakni apa yang kita kenal dengan slide, opaque, OHP dan peralatan visual lainnya bila diberi unsur suara dari rekaman kaset yang dimanfaatkan secara bersamaan dalam satu waktu atau proses pembelajaran tetapi tidak mengubah hakikatnya sebagai peralatan media visual (Munadi, 2008:113-114).

Ditinjau dari segi teknis, yang dimaksud dengan pembelajaran audio visual menunjuk pada beberapa macam perangkat keras yang dipakai guru untuk menyampaikan ide dan pengalaman melalui mata dan telinga. Perbedaan utama antara pembelajaran audiovisual dengan teknik instruksional lainnya sekedar terletak pada masalah penekanan. Pembelajaran audiovisual memberikan tekanan pada pengalaman konkrit atau non-verbal dalam proses belajar, sedangkan teknik instruksional lainnya pada pengalaman verbal dan simbolis.

Sekalipun pembelajaran audio visual menambahkan komponen audio ke dalam aliran pembelajaran visual, namun penambahan konseptual hanya sedikit. Aliran ini tetap mempertahankan rentangan (continuum) abstrak - konkrit (dengan bahan audiovisual pada ujung yang lebih konkrit) serta mengklasifikasikan jenis bahan, dan bukannya sekedar mendaftar jenis bahan itu.

Menurut beberapa ahli seperti Ruch, Mussen, Rosenzweing dan Arendt dikutip Rakhmat (1998) bahwa, berpikir merupakan proses abstraksi manusia dengan menggunakan lambang-lambang. Lambang-lambang ini yang selanjutnya diterjemahkan oleh Hannah sebagai bahasa. Tetapi dalam beberapa karya besar Aristoteles, justru bahasa digunakan setelah proses berpikirnya tuntas. Dari kedua pandangan ini, memberikan kejelasan bahwa bahasa dan berpikir berhubungan erat dan tak terpisahkan. Untuk memudahkan mengingat kembali dan mengkomunikasikan hasil berpikirnya manusia membutuhkan bahasa. Dengan bahasa pula seseorang beroleh informasi-informasi, informasi-informasi tersebut selanjutnya akan memperkaya khasanah berpikirnya.Berpikir itu terkait dengan kerja-kerja otak manusia.

Guilford (1981) membagi kemampuan berpikir dalam tiga kategori; (a) kognitif, (b) produktif, dan (c) evaluatif. Kemampuan berpikir produktif dibagi menjadi dua, yaitu; (a) konvergen, dan (b) divergen. Pemikiran konvergen bergerak menuju jawaban tertentu atau konversional, sebaliknya pemikiran divergen bergerak ke berbagai arah, tidak menuju ke jawaban yang tersedia. Menurutnya pemikiran konvergen terfokus pada penyelesaian tepat-tunggal, sedangkan berpikir divergen dapat menghasilkan berbagai penyelesaian. Berpikir konvergen dan divergen merupakan hasil kerja belahan-belahan otak. Berpikir konvergen adalah cara berpikir yang menghasilkan satu jawaban tepat, sedangkan berpikir divergen menghasilkan beberapa kemungkinan jawaban untuk tiap persoalan. Jelaslah bahwa berpikir divergen memberikan ruang yang lebih longgar atas pemunculan ideide kemungkinan jawaban setiap permasalahan. Karena kelonggaran ini, maka berpikir divergen disinonimkan dengan berpikir kreatif.

Menurut Coleman dan Hamman yang dikutip Sukmadinata (2004: 177), berpikir kreatif adalah berpikir yang menghasilkan metode baru, konsep baru ,pengertian baru ,perencanaan baru dan seni baru. Orang berpikir kreatif karena ada kegiatan yang kuat pada pribadinya untuk menghasilkan suatu kemajuan , akibat dari adanya dorongan untuk berprestasi yang tinggi serta adanya kesadaran akan pentingnya sesuatu yang baru tersebut. Berpikir kreatif sangat erat hubungannya dengan kreatifitas , karena kreativitas adalah hasil dari proses berpikir kreatif yang dilakukan seseorang. Inovasi adalah penerapan secara praktis gagasan yan kreatif. Berpikir kreatif adalah proses yang digunakan ketika mengajukan suatu gagasan baru. Kriteria baru ini bergantung pada pandangan individu, kelompok ataupun masyarakat di sekitarnya.Berdasarkan analisis faktor, Guilford (1981) menemukan , bahwa ada 5 sifat yang menjadi kemampuan berpikir kreatif : 1) fluensy (kelancaran) adalah kemampuan untuk menghasilkan banyak gagasan; 2) flexibility 
(keluwesan) adalah kemampuan untuk mengemukakan bermacam-macam pemecahan atau pendekatan terhadap masalah, 3) originality (keaslian) adalah kemapuan untuk mencetuskan gagasan dengan cara-cara yang asli , tidak klise; 4) elaboration (pengurain) adalah kemampuan untuk menguraikan sesuatu secara terinci; 5) redefinition (perumusan kembali) adalah kemampuan untuk meninjau suatu persoalan berdasrkan perspektif yang berbeda dengan apa yang sudah diketahui oleh banyak orang.

Berdasarkan teori dan definisi di atas, maka yang dimaksud dengan berpikir kreatif adalah bentuk pemikiran individu melalui tahapan-tahapan berpikir berupa; (a) persiapan (b) inkubasi, (c) iluminasi, dan (d) verifikasi, untuk menemukan hubungan-hubungan baru, jawaban, metode baru dalam menanggapi suatu persoalan untuk memecahkan masalah, yang dicirikan oleh; (a) kepekaan dalam pengamatan, (b) kelancaran berpikir, (c) keluwesan berpikir, (d) keaslian berpikir, (e) mendefinisikan kembali, (f) menguraikan, (g) menilai, (h) minat, (i) ketaatan pada aturan, (j) menerima hal-hal baru, (k) mengkhayal, (1) percaya pada diri sendiri atau tidak terikat pada konvensi sosial, dan (m) bertindak.

Berdasarkan uraian di atas dapat disimpulkan bahwa berpikir kreatif adalah suatu bentuk pemikiran untuk menemukan metode atau cara-cara yang baru dalam menanggapi suatu persoalan untuk memecahkan masalah. Jadi kemampuan berpikir kreatif adalah kemampuan yang dimiliki oleh pemikiran seseorang untuk mengciptakan maupun menemukan metode atau cara-cara baru dalam menanggapi suatu persoalan serta menemukan pemecahan masalah dari persoalan yang ada.

Dalam International Interdisciplinary Journal of Education - April 2012 Volume 1, Issue 3 disebutkan hasil hipotesis secara statistik menyatakan ada hubungan yang signifikan antara berpikir kreatif dan hasil pencapaian akademik siswa pada aspek yang berbeda dari tes berpikir kreatif. Namun, hubungan tersebut bisa saja berubah bila tingkat pencapaian akademisnya berbeda dan ketika pengukuran berpikir kreatif digunakan. Studi ini memiliki implikasi yang cukup besar untuk pendidikan secara keseluruhan. Pemikiran kreatif bervariasi dari ide yang sama sekali baru hingga cara baru dalam mengatasi dan memecahkan masalah. Dikatakan bahwa kreativitas bukanlah kemampuan untuk menciptakan apa-apa, tapi kemampuan untuk menghasilkan gagasan baru dengan menggabungkan, mengubah atau menerapkan kembali gagasan-gagasan yang ada. Pemikiran kreatif melibatkan pembuatan sesuatu yang baru atau asli. Ini melibatkan keterampilan fleksibilitas, orisinalitas, kefasihan, citra, pemikiran asosiatif, daftar atribut, pemikiran metaforis dan hubungan paksa. Tujuan pemikiran kreatif adalah menstimulasi rasa ingin tahu dan mempromosikan divergensi.

Hipotesis penelitian ini adalah: (1) Hasil belajar Reading Comprehension siswa yang diajar dengan pemanfaatan media pembelajaran berbasis komputer lebih tinggi dibandingkan dengan hasil belajar siswa yang diajar dengan media pembelajaran berbasis audio visual ; (2) Hasil belajar Reading Comprehension siswa yang memiliki kemampuan berpikir kreatif tinggi lebih tinggi dibandingkan dengan hasil belajar siswa yang memiliki kemampuan berpikir kreatif rendah; dan (3) Terdapat interaksi antara media pembelajaran dengan kemampuan berpikir kreatif dalam mempengaruhi hasil belajar Reading Comprehension siswa.

\section{METODE}

Penelitian ini dilaksanakan di Sekolah Menengah Pertama (SMP) Swasta Methodist 6 Medan. Perlakuan atau treatment penelitian dilaksanakan dengan menyesuaikan jadwal mata pelajaran Reading Comprehension. Populasi dalam penelitian ini adalah seluruh siswa kelas VIII (delapan) SMP Swasta Methodist 6 Medan, terdiri dari 3 (tiga) kelas yaitu kelas VIII-A $=41$ orang, VIII-B $=40$ orang, dan VIII-C $=40$ orang dengan jumlah keseluruhan 121 orang. Dari keseluruhan populasi ditetapkan 2 (dua) kelas yang menjadi sampel. Masing-masing kelas memiliki karakteristik yang sama seperti penggunaan kurikulum, setiap kelas tidak memiliki siswa yang pernah tinggal kelas dan rata-rata memiliki umur yang tidak jauh berbeda. Sampel penelitian diperoleh dengan menggunakan cara cluster random sampling atau teknik pengambilan sampel secara acak. Dengan menggunakan teknik sampling di atas terpilih kelas VIII-C sebagai kelas eksperimen (kelas yang diberi perlakuan dengan media pembelajaran berbasis komputer) dengan jumlah 40 orang dan kelas VIII-A sebagai kelas kontrol (kelas yang diberi perlakuan 
dengan media pembelajaran berbasis audio visual) dengan jumlah 41 orang.

Metode yang dipergunakan dalam penelitian ini adalah metode quasi eksperimen dengan desain penelitian faktorial $2 \times 2$. Melalui desain ini akan melibatkan dua kelompok sampel masing-masing ditetapkan sebagai kelompok eksperimen dengan menggunakan media pembelajaran berbasis komputer dan media pembelajaran berbasis audio visual dalam pembelajaran Reading Comprehension. Akhir dari eksperimen ini diharapkan mendapat informasi tentang perbedaan hasil belajar Reading Comprehension melalui media pembelajaran berbasis komputer yang dibandingkan dengan media pembelajaran berbasis audio visual. Media pembelajaran berbasis komputer dan media pembelajaran berbasis audio visual sebagai variabel bebas sedangkan kemampuan berpikir kreatif dibagi menjadi kemampuan berpikir kreatif tinggi dan kemampuan berpikir kreatif rendah sebagai variabel moderator dan hasil belajar Reading Comprehension sebagai variabel terikat. Berikut ditunjukkan variabelvariabel tersebut dalam Tabel 1 .

Tabel 1. Rancangan Ekesperimen Desain Faktorial 2 x 2

\begin{tabular}{|c|c|l|}
\hline $\begin{array}{l}\text { Strategi pembelajaran } \\
\text { Kemampuan } \\
\text { berpikir kreatif }(\mathbf{B})\end{array}$ & $\begin{array}{c}\text { Media Berbasis } \\
\text { Komputer } \\
\left(\mathbf{A}_{1}\right)\end{array}$ & $\begin{array}{l}\text { Media Berbasis Audio } \\
\text { Visual }\end{array}$ \\
\hline Tinggi $\left(\mathrm{B}_{1}\right)$ & $\mathrm{A}_{1} \mathrm{~B}_{1}$ & $\mathrm{~A}_{2} \mathrm{~B}_{1}$ \\
\hline Rendah $\left(\mathrm{B}_{2}\right)$ & $\mathrm{A}_{1} \mathrm{~B}_{2}$ & $\mathrm{~A}_{2} \mathrm{~B}_{2}$ \\
\hline
\end{tabular}

Keterangan:

$\mathrm{A}=$ Media pembelajaran

$\mathrm{A}_{1}=$ Media pembelajaran berbasis komputer

$\mathrm{A}_{2}=$ Media pembelajaran berbasis audio visual

$\mathrm{B}=$ kemampuan berpikir kreatif

$\mathrm{B}_{1}=$ kemampuan berpikir kreatif tinggi

$\mathrm{B}_{2} \quad=$ kemampuan berpikir kreatif rendah

$\mathrm{A}_{1} \mathrm{~B}_{1}=$ Hasil belajar Reading Comprehension yang diajar dengan media pembelajaran berbasis komputer dan memiliki kemampuan berpikir kreatif tinggi

$\mathrm{A}_{1} \mathrm{~B}_{2}=$ Hasil belajar Reading Comprehension yang diajar dengan media pembelajaran berbasis komputer dan memiliki kemampuan berpikir kreatif rendah

$\mathrm{A}_{2} \mathrm{~B}_{1}=$ Hasil belajar Reading Comprehension yang diajar dengan media pembelajaran berbasis audio visual dan memiliki kemampuan berpikir kreatif tinggi

$\mathrm{A}_{2} \mathrm{~B}_{2}=$ Hasil belajar Reading Comprehension yang diajar dengan media pembelajaran berbasis audio visual dan memiliki kemampuan berpikir kreatif rendah

Teknik analisis data yang digunakan adalah Teknik Statistik Deskriptif dan Inferensial. Teknik statistik deskriptif digunakan untuk mendeskripsikan data, antara lain: nilai rata-rata (mean), median, modus, standard deviasi dan kecenderungan data. Teknik statistik Inferensial digunakan untuk menguji hipotesis penelitian, di mana teknik Inferensial yang akan digunakan adalah teknik Analisis Varians (ANAVA) dua jalur (disain faktorial 2x2) dengan taraf signifikan $5 \%$. Sebelum ANAVA dua jalur dilakukan, terlebih dahulu dilakukan uji persyaratan analisis yakni uji persyaratan normalitas menggunakan Uji Chi-Kuadrat, sedangkan untuk uji persyaratan homogenitas menggunakan Uji F dan Uji Bartlett (Sudjana, 2005: 261).

Setelah melakukan pengujian persyaratan analisis, selanjutnya dilakukan pengujian Anava 2 jalur. Uji lanjut dilakukan dengan Uji Tuckey (n sama).

Berdasarkan hipotesis penelitian yang telah dirumuskan di muka, maka berikut ini dapat disusun hipotesis statistik yang akan diuji sebagai berikut:

1. Hipotesis Pertama: Ho $: \mu_{\mathrm{A} 1} \leq \mu_{\mathrm{A} 2}$

2. Hipotesis Kedua: $\quad$ Ho $: \mu_{\mathrm{B} 1} \leq \mu_{\mathrm{B} 2}$

3. Hipotesis Ketiga:

Ho : $\mathrm{A} \times \mathrm{B}=0$

$\mathrm{Ha}: \mathrm{A} \times \mathrm{B} \neq 0$

Keterangan:

$\begin{array}{rlr}\mu_{A 1}= & \begin{array}{l}\text { Rata-rata hasil belajar Reading } \\ \text { Comprehension siswa }\end{array} & \text { yang } \\ & \text { diajarkan dengan } & \text { media } \\ \mu_{A 2}= & \begin{array}{l}\text { pembelajaran berbasis komputer. } \\ \text { Rata-rata hasil belajar }\end{array} & \text { Reading } \\ & \text { Comprehension siswa } & \text { yang } \\ & \text { diajarkan dengan } & \text { media } \\ & \text { pembelajaran berbasis audio visual }\end{array}$




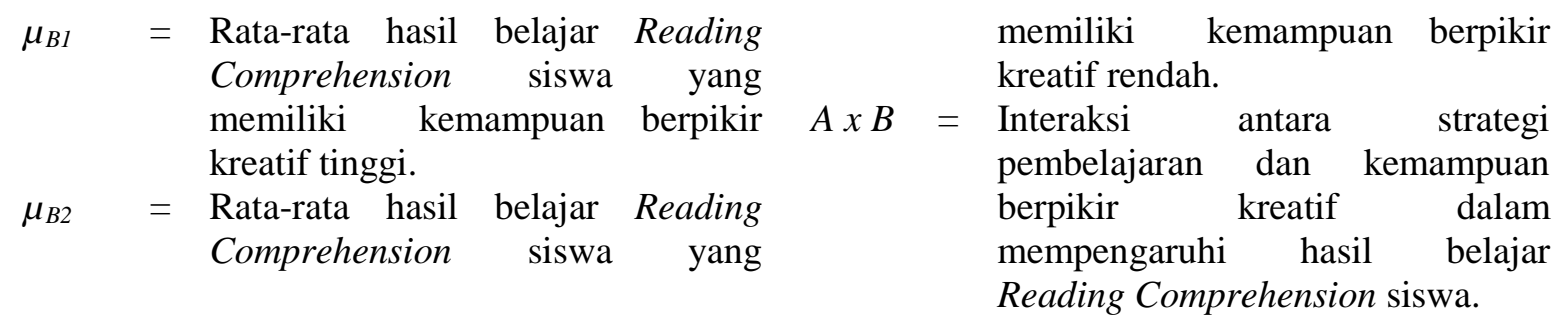

\section{HASIL DAN PEMBAHASAN}

Tabel 2. Rangkuman Data Hasil Perhitungan Analisis Deskriptif.

\begin{tabular}{|c|c|c|c|c|}
\hline \multirow{2}{*}{\multicolumn{2}{|c|}{$\begin{array}{c}\text { RINGKASAN } \\
\text { DATA }\end{array}$}} & \multicolumn{2}{|c|}{ MEDIA PEMBELAJARAN } & \multirow[b]{2}{*}{ JUMLAH } \\
\hline & & $\begin{array}{l}\text { Berbasis } \\
\text { Komputer }\end{array}$ & $\begin{array}{c}\text { Berbasis } \\
\text { Audio Visual }\end{array}$ & \\
\hline \multirow{2}{*}{$\begin{array}{l}\text { KEMAMPUAN } \\
\text { BERPIKIR } \\
\text { KREATIF }\end{array}$} & Tinggi & $\begin{array}{ll}\mathrm{N}_{1} & =16 \\
\Sigma_{\mathrm{X}} & =411 \\
\Sigma_{\mathrm{X}^{2}} & =10675 \\
\bar{X}_{1} & =25,63 \\
\mathrm{Sd}^{2} & =6.65\end{array}$ & $\mid$\begin{tabular}{|l}
$\mathrm{N}_{3}=16$ \\
$\Sigma_{\mathrm{X}}=400$ \\
$\Sigma \mathrm{X}=10084$ \\
$\bar{X}_{3}=25,00$ \\
$\mathrm{Sd}^{2}=5,07$
\end{tabular} & $\begin{aligned} \mathrm{Nt} & =32 \\
\Sigma \mathrm{X} & =811 \\
\Sigma \mathrm{X}^{2} & =20759 \\
\bar{X} & =25,38 \\
\mathrm{Sd}^{2} & =7,21\end{aligned}$ \\
\hline & Rendah & $\begin{array}{ll}\mathrm{N}_{2} & =16 \\
\Sigma X & =378 \\
\Sigma X^{2} & =9026 \\
\bar{X} & =23,75 \\
S^{2} & =6,87\end{array}$ & \begin{tabular}{|l}
$\mathrm{N}_{4}=16$ \\
$\Sigma \mathrm{X}=332$ \\
$\Sigma \mathrm{X}^{2}=7080$ \\
$\bar{X}=20,56$ \\
$\mathrm{Sd}^{2}=11,06$
\end{tabular} & $\begin{array}{l}\mathrm{Nt}=32 \\
\Sigma \mathrm{X}=710 \\
\Sigma \mathrm{X}^{2}=16106 \\
\bar{X}=22,16 \\
\mathrm{Sd}^{2}=11,75\end{array}$ \\
\hline \multicolumn{2}{|c|}{ JUMLAH } & $\begin{array}{l}\mathrm{Nt}=32 \\
\Sigma \mathrm{X}=789 \\
\Sigma \mathrm{X}^{2}=19701 \\
\bar{X}=24,75 \\
\mathrm{Sd}^{2}=15,29\end{array}$ & \begin{tabular}{|ll}
$\mathrm{Nt}$ & $=32$ \\
$\Sigma \mathrm{X}$ & $=732$ \\
$\Sigma \mathrm{X}^{2}$ & $=17164$ \\
$\bar{X}$ & $=22,72$ \\
$\mathrm{Sd}^{2}$ & $=12,98$
\end{tabular} & $\begin{array}{l}\mathrm{Nt}=32 \\
\Sigma X=1583 \\
\Sigma_{X}=36865 \\
\bar{X}=23,77\end{array}$ \\
\hline
\end{tabular}

Untuk keperluan pengujian hipotesis dengan menggunakan teknik analisis varians dua jalur (ANAVA) faktorial 2 × 2 dan uji lanjut Tuckey diperlukan harga rata-rata tiap kelompok. Rangkuman data hasil belajar Reading Comprehension dapat dilihat pada Tabel 2 dengan menggunakan analisis deskriptif. Setelah data Tabel 1 diolah dengan Anava 2 jalur faktorial 2x2, maka diperoleh hasil analisis seperti ditunjukkan pada Tabel 3.

Tabel 3. Ringkasan Hasil Perhitungan ANAVA Faktorial 2x2

\begin{tabular}{|c|c|c|c|c|c|c|}
\hline Sumber varians & dk & JK & RJK & Fh & $\begin{array}{c}\text { Ft } \\
(\alpha=0.05)\end{array}$ & Ket \\
\hline $\begin{array}{l}\text { Strategi Pembelajaran } \\
\text { (A) }\end{array}$ & 1 & 19,14 & 19,14 & 6,2359 & \multirow{5}{*}{4,0012} & Signifikan \\
\hline $\begin{array}{l}\text { Kemampuan berpikir } \\
\text { Kreatif (B) }\end{array}$ & 1 & 28,89 & 28,89 & 19,5811 & & Signifikan \\
\hline Interaksi $(\mathrm{AB})$ & 1 & 9,77 & 9,77 & 2,3514 & & $\begin{array}{c}\text { Tidak } \\
\text { Signifikan }\end{array}$ \\
\hline Dalam Kelompok & 60 & 642,69 & 10,71 & - & & \\
\hline Total & 63 & 700,49 & - & - & & \\
\hline
\end{tabular}


Keterangan:

$\mathrm{dk} \quad=$ Derajat kebebasan

$\mathrm{JK}=$ Jumlah Kuadrat

RJK = Rata-rata Jumlah Kuadrat $(\mathrm{RJK}=$ $\mathrm{JK} / \mathrm{db}$ )

* $\quad=$ Uji F Signifikan (Signifikan pada $\alpha=$ $0,05)$.

Perbedaan Hasil Belajar Reading Comprehension Siswa yang Diajar dengan Media Pembelajaran Berbasis Komputer Lebih Tinggi dengan Siswa yang Diajar dengan Media Pembelajaran berbasis Audio Visual

Ho : $\mu_{\mathrm{A} 1} \leq \mu_{\mathrm{A} 2}$

$\mathrm{Ha}: \mu_{\mathrm{A} 1}<\mu_{\mathrm{A} 2}$

Kriteria pengujian: (1) Ha diterima dan Ho ditolak jika $F_{h}>F_{t}$ serta (2) Ha ditolak dan Ho diterima jika $F_{h}<F_{t}$.

Hasil perhitungan analisis varians tentang rata-rata hasil belajar Reading Comprehension siswa yang diajar dengan media pembelajaran berbasis komputer sebesar $\bar{X}=24,75$ dan rata-rata hasil belajar siswa yang diajar dengan media pembelajaran berbasis audio visual $\bar{X}=22,72$, didapat hasil perhitungan $F_{h}$ sebesar 6,2359 dan harga $F_{t}$ untuk taraf signifikansi $\alpha=0.05$ dengan derajat kebebasan $\mathrm{d}_{\mathrm{k}}(1: 60)$ adalah 4,0012. Didapat $F_{h}(6,2359)>F_{t}(4,0012)$, dengan demikian temuan penelitian menyimpulkan, bahwa Ho ditolak dan Ha diterima. Hipotesis penelitian yang menyatakan: Hasil belajar Reading Comprehension siswa yang diajar dengan menggunakan media pembelajaran berbasis komputer lebih tinggi dibandingkan dengan siswa yang diajar dengan menggunakan media pembelajaran berbasis audio visual pada taraf signifikansi $\alpha=0,05$ telah teruji kebenarannya.

Perbedaan Hasil Belajar Reading Comprehension Siswa yang Memiliki Kemampuan berpikir kreatif Tinggi dengan Hasil Belajar Siswa yang Memiliki Kemampuan Berpikir kreatif rendah.

$$
\text { Ho }: \mu_{\mathrm{B} 1} \leq \mu_{\mathrm{B} 2}
$$$$
\mathrm{Ha}: \mu_{\mathrm{B} 1}<\mu_{\mathrm{B} 2}
$$

Kriteria pengujian: (1) Ha diterima dan Ho ditolak jika $F_{h}>F_{t}$ serta (2) Ha ditolak dan Ho diterima jika $\mathrm{F}_{\mathrm{h}}<\mathrm{F}_{\mathrm{t}}$.

Hasil perhitungan analisis varians tentang rata-rata hasil belajar Sejarah siswa yang memiliki kemampuan berpikir kreatif tinggi sebesar $\bar{X}=25,38$ dan rata-rata hasil belajar Reading Comprehension siswa yang memiliki kemampuan berpikir kreatif rendah
$\bar{X}=22,16$. didapat hasil perhitungan $\mathrm{F}_{\mathrm{h}}$ sebesar 19,5811 dan harga $F_{t}$ untuk taraf signifikansi $\alpha=0.05$ dengan derajat kebebasan $\mathrm{d}_{\mathrm{k}(1: 60)}$ adalah 4,0012. Didapat $\mathrm{F}_{\mathrm{h}}(19,5811)>$ $\mathrm{F}_{\mathrm{t}}(4,0012)$, dengan demikian temuan penelitian menyimpulkan, bahwa Ho ditolak dan $\mathrm{Ha}$ diterima. Hipotesis penelitian yang menyatakan: Hasil belajar Reading Comprehension siswa yang memiliki kemampuan berpikir kreatif tinggi lebih tinggi dibandingkan dengan siswa yang memiliki kemampuan berpikir kreatif rendah pada taraf signifikansi $\alpha=0,05$ telah teruji kebenarannya.

Tidak terdapat Interaksi antara Media Pembelajaran dengan Kemampuan Berpikir kreatif dalam Mempengaruhi Hasil Belajar Reading Comprehension Siswa.

Ho: $\mathrm{A} \times \mathrm{B}=0$

$\mathrm{Ha}: \mathrm{A} \times \mathrm{B} \neq 0$

Kriteria pengujian: (1) Ha diterima dan Ho ditolak jika $F_{h}>F_{t}$ serta (2) Ha ditolak dan Ho diterima jika $F_{h}<F_{t}$.

Hasil perhitungan analisis varians tentang rata-rata hasil belajar Reading Comprehension siswa untuk setiap kelompok perlakuan adalah sebagai berikut: Rata-rata hasil belajar Reading Comprehension siswa yang diajar dengan media pembelajaran berbasis komputer dan memiliki kemampuan berpikir kreatif tinggi $\bar{X}=25,63$ dan hasil belajar Reading Comprehension siswa yang diajar dengan media pembelajaran berbasis komputer dan memiliki kemampuan berpikir kreatif rendah $\bar{X}=23,75$ sedangkan hasil belajar Reading Comprehension siswa yang diajar dengan media pembelajaran berbasis audio visual dan memiliki kemampuan berpikir kreatif tinggi $\bar{X}=25,00$ dan hasil belajar Reading Comprehension siswa yang diajar dengan media pembelajaran berbasis audio visual dan memiliki kemampuan berpikir kreatif rendah $\bar{X}=20,56$. Hasil perhitungan ANAVA faktorial $2 \times 2$ diperoleh hasil perhitungan $F_{h}=2,3514$ dan harga $F_{t}$ untuk taraf signifikansi $\alpha=0.05$ dengan $\mathrm{dk}=(1: 60)$ adalah 4,0012. Didapat $F_{h}(2,3514)<F_{t}$ $(4,0012)$, dengan demikian temuan penelitian menyimpulkan, bahwa Ho diterima dan $\mathrm{Ha}$ ditolak. Hipotesis penelitian yang menyatakan: tidak terdapat interaksi antara media pembelajaran dengan kemampuan berpikir kreatif dalam mempengaruhi hasil belajar Reading Comprehension siswa tidak teruji 
kebenarannya pada taraf signifikansi 0.05 . Hubungan interaksi antara media pembelajaran dengan kemampuan berpikir kreatif dalam mempengaruhi hasil belajar Reading Comprehension siswa dapat divisualisasikan secara grafis pada gambar 1 .

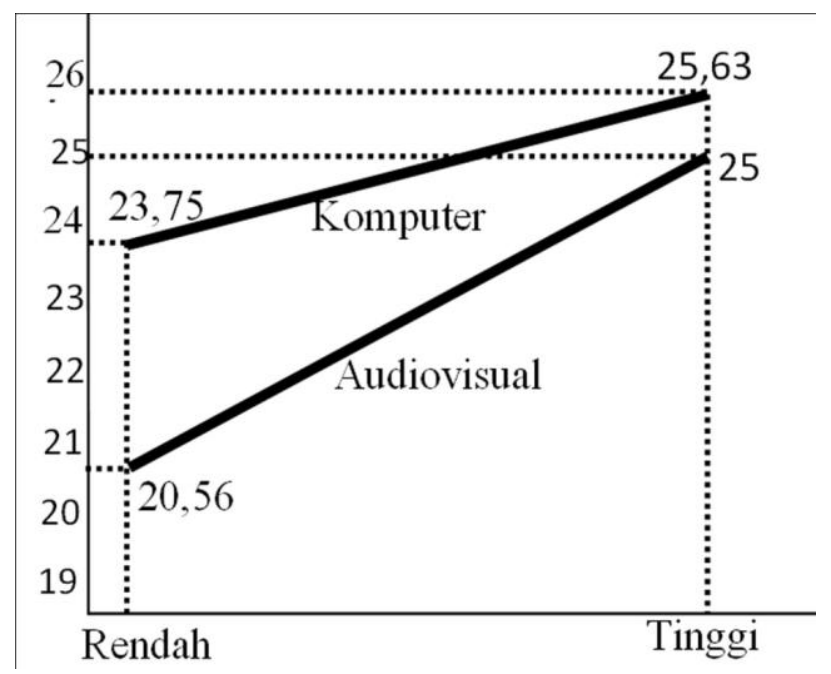

Gambar 1. Interaksi antara Media Pembelajaran dengan Kemampuan Berpikir kreatif dalam Mempengaruhi Hasil Belajar Sejarah Siswa.

Berdasarkan hasil pengujian hipotesis ketiga yang menyatakan tidak terdapat interaksi antara media pembelajaran dengan kemampuan berpikir kreatif dalam mempengaruhi hasil belajar Reading Comprehension siswa, maka tidak perlu dilakukan uji perbedaan rata rata antara dua proposisi untuk itu dengan $\mathrm{Uji}$ Lanjut Tuckey. Gambar 1, menunjukkan tidak terdapat interaksi antara media pembelajaran dengan kemampuan berpikir kreatif dalam mempengaruhi hasil belajar Reading Comprehension siswa, sehingga media pembelajaran berbasis komputer dapat dimanfaatkan oleh siswa yang memiliki kemampuan berpikir kreatif tinggi maupun rendah. Dengan kata lain media pembelajaran berbasis komputer dapat digunakan oleh guru dalam menyampaikan bahan ajar kepada siswa yang memiliki kemampuan berpikir kreatif tinggi maupun rendah, maka pencapaian hasil belajar Reading Comprehension siswa akan semakin tinggi. Dilain pihak faktor kemampuan berpikir kreatif perlu diperhatikan karena terbukti bahwa kemampuan berpikir kreatif berpengaruh terhadap hasil belajar Reading Comprehension siswa.

Guru harus memotivasi, mendorong dan menstimulasi siswa sehingga tujuan belajar dapat terwujud, guru menilai dan mengatur situasi belajar sehingga tercapai tujuan pembelajaran. Untuk itu dibutuhkan media pembelajaran yang mampu untuk mendeskripsikan secara rinci, mendefenisikan dan memahami konsep-konsep serta struktur, memahami teori-teori dan mampu menganalisis serta mengevaluasi mata pelajaran Reading Comprehension agar dapat mengasosiasikannya dalam pembelajaran yang efektif dan efisien. Penggunaan media pembelajaran berbasis komputer dalam Reading Comprehension sangat tepat karena dalam proses pembelajaran yang dilakukan di mulai dari umum-ke-rinci dengan menguraikan lebih mendalam tergantung kedalaman materi serta diberikan sintesis dan rangkuman. Hal ini memungkinkan peserta didik dapat menguasai materi lebih mendalam karena bentuk penyajiannya yang selalu mengaitkan hubungan antara materi yang sedang dipelajari.

Hasil penelitian menunjukkan bahwa hasil belajar Reading Comprehension siswa yang memiliki kemampuan berpikir kreatif tinggi lebih tinggi dibandingkan siswa yang memiliki kemampuan berpikir kreatif rendah, dimana nilai rata-rata hasil belajar Reading Comprehension siswa yang memiliki kemampuan berpikir kreatif tinggi lebih tinggi dibandingkan siswa yang memiliki kemampuan berpikir kreatif rendah.

Hasil penelitian menunjukkan bahwa hasil belajar Reading Comprehension siswa yang memiliki kemampuan berpikir kreatif 
tinggi lebih tinggi dibandingkan siswa yang memiliki kemampuan berpikir kreatif rendah jika diajar dengan media pembelajaran berbasis komputer dimana nilai rata-rata hasil belajar Reading Comprehension siswa yang memiliki kemampuan berpikir kreatif tinggi lebih tinggi dibandingkan siswa yang memiliki kemampuan berpikir kreatif rendah jika diajar dengan strategi pembelajaran berbasis komputer. Tetapi sebaliknya nilai rata-rata hasil belajar Reading Comprehension siswa yang memiliki kemampuan berpikir kreatif tinggi agak tinggi dibandingkan siswa yang memiliki kemampuan berpikir kreatif rendah jika diajar dengan media pembelajaran berbasis audio visual. Hal ini berindikasi bahwa siswa yang memiliki kemampuan berpikir kreatif tinggi lebih mampu memahami secara mendalam terhadap tugas dan materi Reading Comprehension diajar dengan media pembelajaran berbasis komputer.

Siswa yang memiliki kemampuan berpikir kreatif yang tinggi cenderung dapat menyelesaikan persoalannya sendiri tanpa mendapat hambatan yang berarti dan cenderung lebih memilih untuk belajar secara mandiri untuk memecahkan persoalannya sendiri. Siswa yang memiliki kemampuan berpikir kreatif rendah cenderung untuk menyukai cara belajar dan memecahkan persoalannya dengan bantuan orang lain. Siswa yang memiliki kemampuan berpikir rendah lebih menyukai cara belajar berkelompok untuk memecahkan persoalan secara bersama-sama.

Temuan penelitian menunjukkan bahwa tidak terdapat interaksi antara media pembelajaran dengan kemampuan berpikir kreatif dalam mempengaruhi hasil belajar Reading Comprehension siswa. Hasil belajar Reading Comprehension siswa yang diajar dengan media pembelajaran berbasis komputer dan memiliki kemampuan berpikir kreatif tinggi lebih tinggi dibandingkan dengan siswa yang memiliki kemampuan berpikir kreatif rendah. Sedangkan hasil belajar Reading Comprehension siswa yang diajar dengan media pembelajaran berbasis audio visual dan memiliki kemampuan berpikir kreatif rendah kurang tinggi dibandingkan dengan siswa yang memiliki kemampuan berpikir kreatif tinggi. Hal ini memberikan pemahaman bahwa siswa yang memiliki kemampuan berpikir kreatif tinggi maupun rendah cocok diajar dengan media pembelajaran berbasis komputer.

Setiap guru dapat memfokuskan perhatian pada pengembangan materi Reading
Comprehension dengan kompetensi dasar. Guru dapat menyajikan materi pelajaran dengan cara menyampaikan kerangka isi dari kompetensi dasar, kemudian menguraikannya dan menggunakan aplikasi Author Plus membuat materi ajar dan tugas dalam Units atau Exercises yang terdapat di Course. Materi sesuai dengan yang diharapkan dalam tujuan pembelajaran.

Guru harus memotivasi, mendorong dan menstimulasi siswa sehingga tujuan belajar dapat terwujud, guru menilai dan mengatur situasi belajar sehingga tercapai tujuan pembelajaran. Untuk itu dibutuhkan media pembelajaran yang mampu untuk mendeskripsikan secara rinci, mendefenisikan dan memahami konsep-konsep serta struktur, memahami teori-teori dan mampu menganalisis serta mengevaluasi mata pelajaran Reading Comprehension agar dapat mengasosiasikannya dalam pembelajaran yang efektif dan efisien. Penggunaan media pembelajaran berbasis komputer dalam mata pelajaran Reading Comprehension sangat tepat karena ada terdapat berbagai variasi exercises dalam proses pembelajaran yang dilakukan sehingga tidak membosankan bagi siswa dimana siswa dapat mengulang-ulang materi Reading Comprehension dengan topik yang sama tetapi soal-soal exercises yang bervariasi.

Kemampuan berpikir kreatif dapat digunakan untuk mengidentifikasi dan mengklasifikasi rangsangan atau pengaruh berbeda dari luar sehingga siswa dapat dengan cepat dapat beradaptasi menyesuaikan apa yang diketahui dengan apa yang akan dipelajarinya. Kemampuan berpikir kreatif berpengaruh terhadap kemampuan siswa dalam menyelesaikan masalah atau soal-soal Reading Comprehension. Didalam ranah kognitif, belajar Reading Comprehension membutuhkan kemampuan berpikir kreatif tinggi guna menyelesaikan memahami makna yang terkandung di dalam teks. Juga mampu menyatakan generic structures, language features maupun social values yang terdapat di dalam teks. Berdasarkan penjelasan di atas, dapat disimpulkan bahwa terdapat keterkaitan pada proses pembelajaran secara keseluruhan yang dilakukan oleh seorang guru dalam pencapaian hasil belajar yang lebih tinggi. Media pembelajaran yang berbeda memberi pengaruh yang berbeda terhadap hasil belajar siswa dikaitkan dengan motivasi berprestasi yang dimilikinya. 
Siswa yang memiliki kemampuan berpikir kreatif yang tinggi cenderung dapat menyelesaikan persoalannya sendiri tanpa mendapat hambatan yang berarti dan cenderung lebih memilih untuk belajar secara mandiri untuk memecahkan persoalannya sendiri sedangkan siswa yang memiliki kemampuan berpikir kreatif rendah cenderung untuk menyukai cara belajar dan memecahkan persoalannya dengan bantuan orang lain. Siswa yang memiliki kemampuan berpikir kreatif rendah lebih menyukai cara belajar berkelompok untuk memecahkan persoalan secara bersama-sama.

Siswa yang memiliki kamampuan berpikir kretaif tinggi apabila diberi perlakuan dengan media pembelajaran berbasis komputer akan memperoleh hasil belajar lebih tinggi dibandingkan dengan menggunakan media pembelajaran berbasis audio visual, sebab siswa yang memiliki kamampuan berpikir kreatif tinggi mampu menemukan sendiri pengetahuan dan keterampilan yang dibutuhkannya dengan cara mengaitkan antara pengetahuan dan keterampilan dasar yang telah dimiliki dengan pengetahuan dan keterampilan baru yang dibutuhkannya. Siswa dengan kemampuan berpikir logis tinggi jika dibelajarkan dengan media pembelajaran berbasis komputer akan mampu berpikir secara kreatif dan rasional dalam menyelesaikan soal-soal secara rinci, terurut, dan menggunakan langkah-langkah penyelesaian soal secara sistematis, karena mampu mengaitkan antara materi yang sudah dikuasai dengan materi yang akan dipelajari olehnya.

Untuk siswa yang memiliki kemampuan berpikir kreatif rendah jika diajar dengan media pembelajaran berbasis audio visual akan memperoleh hasil belajar Reading Comprehension kurang tinggi dibandingkan jika diajar dengan media pembelajaran berbasis komputer.

Berdasarkan penjelasan di atas, dapat disimpulkan bahwa terdapat keterkaitan pada proses pembelajaran secara keseluruhan yang dilakukan oleh seorang guru dalam pencapaian hasil belajar yang lebih tinggi. Media pembelajaran yang berbeda memberi pengaruh yang berbeda terhadap hasil belajar siswa dikaitkan dengan kemampuan berpikir kreatif yang dimilikinya. Temuan penelitian di atas mengindikasikan tidak adanya interaksi antara media pembelajaran dengan kemampuan berpikir kreatif dalam mempengaruhi hasil belajar Reading Comprehension siswa.

Adapun beberapa kesalahan yang mungkin terjadi pada penelitian ini dapat disebabkan oleh hal-hal berikut ini :1) siswa (sampel) tidak teliti atau kurang memahami peryataan-pernyataan yang ada pada saat pengisian instrumen kemampuan berpikir kreatif sehingga pilihan-pilihan jawaban pada instrumen yang diisi siswa tidak mewakili kondisi kemampuan berpikir kreatif siswa yang sebenarnya. Ketidakmampuan siswa untuk mengisi intrumen kemampuan berpikir kreatif ini disebabkan bahasa yang digunakan oleh penguji terlalu ilmiah dan siswa masih belum bisa memahaminya pada tingkat usia kelas VIII SMP; 2) Guru tidak menjelaskan dengan terperinci tentang prosedur pada saat pengisian instrumen kemampuan berpikir kreatif, tidak diawasi dengan ketat dan siswa tidak fokus mengerjakan isntrumen yang ada sehingga memberikan jawaban yang kurang tepat seperti yang diharapkan dari hasil tes instrumen ini; 3) pada saat guru melaksanakan perlakuan dengan media pembelajaran berbasis komputer yang menggunakan aplikasi Author Plus kepada siswa, guru tidak menjelaskan dengan benar tentang prosedur penggunaan aplikasi tersebut sehingga siswa tidak mampu menggunakan aplikasi tersebut dengan benar. Hal ini menyebabkan keterlambatan untuk menyelesaikan soal-soal bahasa Inggris maupun tidak dapat mengerjakan semua soal yang ada karena waktu sudah habis; 4) guru tidak serius mendengarkan pengarahan dari peneliti saat menjelaskan prosedur untuk menggunakan aplikasi Author Plus pada kegiatan pembelajaran bahasa Inggris dengan memanfaatkan media pembelajaran berbasis komputer sehingga guru tidak mampu mengarahkan siswa dengan benar saat mengerjakan soal-soal bahasa Inggris dengan aplikasi Author Plus; 5) terjadi kesalahan saat melaksanakan pre test maupun post test di kelas perlakuan karena guru kurang ketat mengawasi siswa sehingga siswa tidak serius mengerjakan pre test maupun post test yang diberikan oleh peneliti sehingga siswa memberikan jawaban yang kurang tepat; 6) guru belum terbiasa memanfaatkan media pembelajaran berbasis komputer di kelas karena selama ini guru sudah terbiasa menerapkan metode ceramah dalam kegiatan pembelajaran yang konvensional, jadi guru masih menggabungkan media cetak dan media berbasis komputer pada pertemuan di 
kelas selama proses penelitian ini berlangsung; 7) guru belum menguasai IPTEK dengan benar khususnya penggunaaan komputer yang digabung dengan aplikasi pembelajaran yang lain; 8) jumlah sampel masih sedikit yang menyebabkan dalam perhitungan hasil dari $F_{\text {hitung }}<F_{\text {tabel }}$ sehingga tidak terjadi interkasi pada pengujian hipotesis ketiga. Kemungkinan akan terjadi interaksi apabila jumlah sampel pada penelitian ditambah lagi.

Dalam International Inter disciplinary Journal of Education - April 2012 Volume 1, Issue 3 disebutkan hasil hipotesis secara statistik menyatakan ada hubungan yang signifikan antara berpikir kreatif dan hasil pencapaian akademik siswa pada aspek yang berbeda dari tes berpikir kreatif. Namun, hubungan tersebut bisa saja berubah bila tingkat pencapaian akademisnya berbeda dan ketika pengukuran berpikir kreatif digunakan.

\section{PENUTUP}

Berdasarkan hasil pengujian hipotesis seperti yang telah diuraikan, penelitian ini menyimpulkan bahwa:

1. Media pembelajaran berbasis komputer sama efektif dengan media pembelajaran berbasis audio visual dalam meningkatkan hasil belajar bahasa Inggris siswa kelas VIII SMP Swasta Methodist 6.

2. Hasil belajar bahasa Inggris siswa yang memiliki kemampuan berpikir kreatif tinggi tidak berbeda jauh dengan hasil belajar bahasa Inggris siswa yang memiliki kemampuan berpikir kreatif rendah
3. Tidak terdapat interaksi antara media pembelajaran dan kemampuan berpikir kreatif yan dimiliki siswa.

Karena tidak ada interaksi antara media pembelajaran dengan kemampuan berpikir kreatif sebagaimana disebutkan di atas, maka tidak perlu dilakukan uji lanjut pada penelitian ini.

\section{DAFTAR PUSTAKA}

Riyanto Y. (2012). Paradigma Baru Pembelajaran. Jakarta: Prenada Media

Setijadi. (1977). Definisi Teknologi Pendidikan. Seri Pustaka Teknologi Pendidikan No. 7. Jakarta: CV Rajawali.

Miarso, Yusufhadi, (2011). Menyemai Benih Teknologi Pendidikan. Jakarta: Kencana Prenada Media Group.

Arsyad, Azhar. (2014). Media Pembelajaran. Jakarta: Rajawali Press Hamzah B. Uno dan Nina Lamatenggo, Teknologi Komunikasi dan Informasi Pembelajaran, Jakarta: PT Bumi Aksara, 2011, cet, 2

Munadi, Yudhi. 2008. Media Pembelajaran. Jakarta : GP Press.

Jalaludin, Rakhmat. (1998). Psikologi Komunikasi. Bandung: Rosda

Guilford,J.P. 1995. Traits of Creativity, dalam h.h Anderson (Ed) Creativity and Its Cultivation. John Wiley,New York.

Sukmadinata. Nana Syaodih (2004). Landasan Psikologi Proses Pendidikan. Bandung: PT remaja Rosdakarya. 